\title{
Bubaline Diaphragm Matrix: Development and Clinical Assessment into Cattle Abdominal Hernia Repair
}

\author{
Shruti Dineshbhai Vora ${ }^{1}$ \\ https://orcid.org/0000-0002-3888-6826 \\ Vineet Kumar ${ }^{*}$ \\ https://orcid.org/0000-0001-7054-5987 \\ Foram Arvindbhai Asodiya ${ }^{1}$ \\ https://orcid.org/0000-0002-7953-2442 \\ Vivek Kumar Singh ${ }^{2}$ \\ https://orcid.org/0000-0002-3335-4396 \\ Dhaval Tribhovanbhai Fefar ${ }^{3}$ \\ https://orcid.org/0000-0002-4561-7106 \\ Harsukh Popatbhai Gajera ${ }^{4}$ \\ https://orcid.org/0000-0001-6177-5414
}

\begin{abstract}
${ }^{1}$ Junagadh Agricultural University, College of Veterinary Science and Animal Husbandry, Department of Veterinary Surgery and Radiology, Junagadh, Gujarat, India; 2Junagadh Agricultural University, College of Veterinary Science and Animal Husbandry, Department of Veterinary Physiology and Biochemistry, Junagadh, Gujarat, India; 3Junagadh Agricultural University, College of Veterinary Science and Animal Husbandry, Department of Veterinary Pathology, Junagadh, Gujarat, India; 4 Junagadh Agricultural University, Department of Biotechnology, Junagadh, Gujarat, India
\end{abstract}

Received: 2018.08.19; Accepted: 2019.06.23.

*Correspondence: bharadwaj374@gmail.com; Tel.: +91-93-04141435

\section{HIGHLIGHTS}

- Treatment with $2 \%$ SDS for $48 \mathrm{~h}$ results in $92.54 \%$ reduction in DNA contents and complete acellularity of the bubaline diaphragm.

- FTIR spectrum of decellularized diaphragm has shown all characteristic transmittance peaks of the collagen.

- Bubaline diaphragm matrix shows excellent repair efficiency and biocompatibility for abdominal hernia repair in cattle without complications. 
Abstract: The purpose of the study was to develop a xenogenic bubaline diaphragm matrix (BDM) for abdominal hernia repair. A fresh diaphragm was decellularized using aqueous sodium dodecyl sulfate (SDS) solutions $(0.5-4 \% \mathrm{w} / \mathrm{v})$ over a period. Acellularity was confirmed histologically and characterized by Masson's trichrome staining, scanning electron microscopy (SEM), DNA quantification, agarose gel electrophoresis, and Fourier-transform infrared spectroscopy. The BDM was used for clinical abdominal hernia repair in six cattle. Clinical, hemato-biochemical and antioxidant parameters were evaluated to assess biocompatibility of xenogenic BDM. Histologically, the diaphragm treated with $2 \%$ SDS for $48 \mathrm{~h}$ showed complete acellularity and orderly arranged collagen fibers. The SEM confirmed preservation of collagen structure and integrity. The DNA content was significantly $(P<0.05)$ reduced in BDM (33.12 $\pm 5.40 \mathrm{ng} / \mathrm{mg})$ as compared to the native diaphragm (443.96 \pm 162.60 $\mathrm{ng} / \mathrm{mg}$ ). DNA extracts from BDM show considerable removal of DNA material, with absence of DNA band in agarose gel. The FTIR spectrum of BDM has shown all characteristic transmittance peaks of bovine skin collagen indicating preserved collagen structure. Six cattle with BDM implant recovered uneventfully and remained sound at least upto 6 months. Hemato-biochemical and antioxidant findings were unremarkable. Bubaline diaphragm matrix shows excellent repair efficiency and biocompatibility for abdominal hernia repair in cattle without complications.

Keywords: Biocompatibility; Bubaline diaphragm matrix; DNA quantification; spectroscopy; Scanning electron microscopy.

\section{GRAPHICAL ABSTRACT}

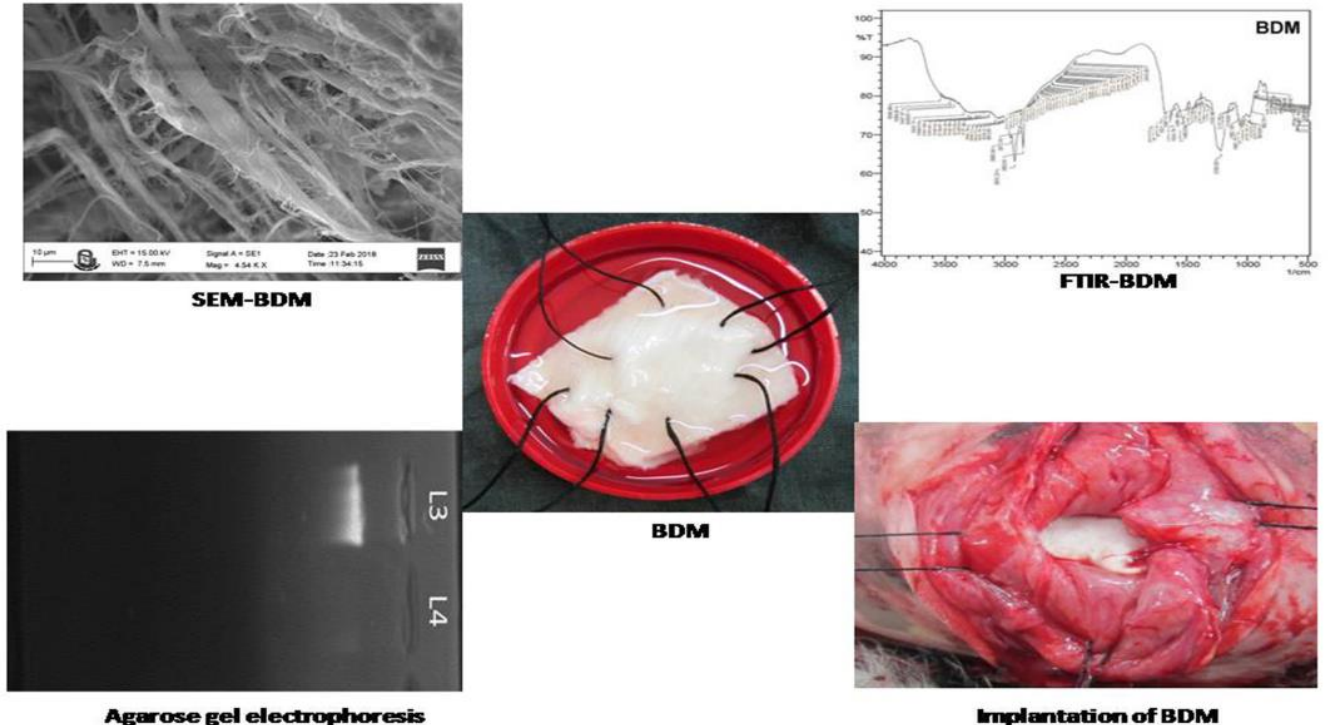

\section{INTRODUCTION}

The abdominal hernia ( $>3 \mathrm{~cm}$ in diameter) often addressed surgically by synthetic mesh placement [1] but failed to elicit cues similar to biological scaffolds. Biological scaffolds are composed of extracellular matrix (ECM) and can be used for repair and regeneration of large soft tissue defects including abdominal hernias. They provide necessary support for cell adhesion, proliferation, phenotypic differentiation, and offer a biochemical and biophysical cues to modulate the neo-tissue formation [2]. They are 
typically prepared by decellularization of source tissues. Inadequate decellularization of the source tissue may result in retained cellular antigens. Those cellular antigens are recognized as foreign by the host and elicit proinflammatory response or overt immunemediated rejection of the tissue [3]. Effective removal of the antigen associated with cell membranes and intracellular components of tissues is necessary to avoid or minimize an adverse immunologic response by xenogenic recipients [4,5]. The ideal decellularization technique removes cells and cellular remnants leaving behind acellular ECM scaffold which can retain the original collagen architecture intact [6]. Recently, it has been shown that decellularization of source tissues can be assessed by quantification of remnant DNA [7]. Fourier-transform infrared (FTIR) spectroscopy is another tool for investigation of chemical compounds [8], and shown potential for qualitative and quantitative analysis of biological samples [9]. Present study was designed to develop bubaline diaphragm matrix (BDM) and test the biocompatibility of the developed matrix for abdominal hernia repair in cattle.

\section{MATERIAL AND METHODS}

\section{Chemical and reagents}

All the chemicals and reagents used in the present study were of highest purity available and obtained from Sigma-Aldrich (St. Louis, MO, USA) unless otherwise mentioned.

\section{Collection, transportation and preparation of the BDM}

Fresh diaphragm (tendinous portion) of bubaline origin was collected from a local abattoir in chilled $\left(4{ }^{\circ} \mathrm{C}\right)$ sterile phosphate buffered saline (PBS, $\mathrm{pH} 7.4$ ), containing $0.048 \%$ gentamicin, $0.0205 \%$ EDTA and $0.1 \%$ sodium azide, and processed immediately. After initial washing, diaphragm tissue was subjected to $0.5,1,2,3$ and $4 \%$ sodium dodecyl sulfate (SDS) solution, respectively. The tissue was continuously agitated at the rate of $250 \mathrm{rpm}$ in SDS solutions on magnetic stirrer (C-MAG HS7, IKA, USA) for 12, 24, 48, and $72 \mathrm{~h}$ at room temperature. Prepared BDM was extensively rinsed with sterile PBS to remove residual detergent and stored in sterile PBS containing $0.048 \%$ gentamicin at $-20^{\circ} \mathrm{C}$ till clinical use. Sterility test of stored sterile PBS was performed to check any bacterial or fungal growth.

\section{Characterization of the BDM}

\section{Histology}

The native and SDS treated diaphragm tissues were fixed in 10\% neutral buffered formalin, serially dehydrated with ethanol, cleared in xylene and embedded in paraffin wax. Tissue sections $(6 \mu \mathrm{m})$ were cut on a semi-automated rotary microtome (RM2245, Leica Microsystems, Wetzlar, Germany) and stained with hematoxylin and eosin (H\&E). Special staining protocol using Masson's trichrome stain (MTS) was performed to identify collagen fibres. Slides were examined under 10 magnifications using an upright compound microscope (Axiocam ERc5s, Primo star, Carl Zeiss, Germany).

\section{Scanning electron microscopy (SEM)}

The native and decellularized diaphragm tissues were cut in small pieces and washed in chilled PBS (0.1 M; pH 7.2) and subjected to fixation in $2.5 \%$ glutaraldehyde in 0.1 M PBS (pH 7.2) for 6 h. Fixed samples were washed in 0.1 M PBS with three times for 15 minutes each at $4{ }^{\circ} \mathrm{C}$. Thereafter, samples were dehydrated in ascending grade of acetone solution viz. $30,50,70,80,90,95$, and $100 \%$, respectively at $4{ }^{\circ} \mathrm{C}$ for 15 minutes. Thereafter, samples were mounted on aluminium stubs, coated with gold palladium in Emitech SC620 sputter coater and topographical imaging of processed tissues were performed using a scanning electron microscope (EVO-18, Carl Zeiss, Germany). 


\section{DNA extraction, quantification and purity}

DNA was extracted from native and decellularized diaphragm tissues by phenol: chloroform: isoamyl alcohol method described by Green and Sambrook [10] with slight modifications. Two hundred milligrams of native and decellularized diaphragm tissues were separately triturated in $1 \mathrm{~mL}$ lysis buffer (Tris: $50 \mathrm{mM}$; EDTA: $0.1 \mathrm{M}$; SDS: $1 \%$ ) using glass Teflon tissue homogenizer, and lysates were incubated for $2 \mathrm{~h}$ at $37^{\circ} \mathrm{C}$ in a water bath. To each tissue homogenate, $50 \mu \mathrm{L}$ Proteinase $\mathrm{K}$ solutions $(20 \mathrm{mg} / \mathrm{mL})$ was added and incubated overnight at $56{ }^{\circ} \mathrm{C}$. Thereafter, tissue homogenates were centrifuged at 10,000 rcf for 10 minutes at room temperature. Supernatants were collected, and equal volume of Tris-saturated phenol $(\mathrm{pH} 8.0)$ was added and mixed gently. Samples were again centrifuged at 10,000 rcf for 10 minutes and upper aqueous phase was transferred to new tube. Equal volume of chloroform: isoamyl alcohol (24:1) mixture was added and mixed gently. Samples were again centrifuged at 10,000 rcf for 10 minutes and aqueous phase was transferred in separate tube. The DNA was precipitated with 2 volumes of absolute ethanol and 0.2 volume of $3 \mathrm{M}$ sodium acetate ( $\mathrm{pH}$ 5.2). Tubes were centrifuged at 10,000 rcf for 10 minutes and supernatant was discarded. Pellets were then washed two times in $70 \%$ ethanol and air dried. Dissolved in nuclease free water and kept in $-20{ }^{\circ} \mathrm{C}$ till further use. After extraction, DNA concentration and purity was quantified using Nanodrop 2000 spectrophotometer (Thermo Scientific, USA). Further, samples were separated by electrophoresis on a $0.8 \%$ low electroendosmosis (EEO) agarose gel with Ethidium Bromide $(0.2 \mu \mathrm{g} / \mathrm{mL})$ at $60 \mathrm{~V}$ for $1 \mathrm{~h}$ stained and visualized with ultraviolet transillumination (FluorShot PRO II SC850, Shanghai Bio-Tech Co., Ltd, China) to confirm DNA integrity.

\section{Fourier transform infrared (FTIR) spectroscopy}

One milligram of each freeze-dried native and decellularized diaphragm tissues were mixed with pure dry $\mathrm{KBr}$ powder in 1:10 ratio, and pelleted. FTIR spectra were recorded by an infrared spectrophotometer (FTIR 8400s Shimadzu Corporation, Tokyo, Japan) in the $500-4000 \mathrm{~cm}^{-1}$ wave number spectral range with a spectral resolution of 2 $\mathrm{cm}^{-1}$ and 45 scans.

\section{Implantation of the BDM in cattle and evaluation}

All methods involving animals were carried out under a protocol approved by the Institute Animal Ethics Committee. The study was conducted on six cattle clinically affected with abdominal hernias. Mean weight of animals was $132.50 \pm 21.86 \mathrm{~kg}$, and mean age $6.50 \pm 1.50$ months. Presence of hernia was confirmed by palpation, radiographic and ultrasonographic examinations. Mean size of the hernial ring was $141.52 \pm 12.43 \mathrm{~cm}^{2}$. Abdominal hernioplasty using BDM scaffold was performed under strict asepsis. All owners granted written informed consent prior to implantation. BAM scaffold was implanted as previously described [11]. All efforts were made to minimize the animal suffering. Biocompatibility of the BDM scaffold in cattle was assessed by below mentioned parameters.

\section{Clinical evaluation}

Body temperature, and respiratory and heart rates were recorded before and on postimplantation day 7 and 15. In addition, animals were observed daily for local or systemic complications, including dehiscence, infection and recurrence at least up to 6 months.

\section{Hematological evaluation}

Complete blood count and erythrocyte sedimentation rate (ESR) were performed before and on post-implantation day 7 and 15 for assessment of adverse responses to implantation. Hematological parameters like hemoglobin $(\mathrm{Hb})$, packed cell volume (PCV), total erythrocyte count (TEC), total leukocyte count (TLC) and differential 
leukocyte count were estimated using automated hematology analyzer (Abacus Junior Vet 5, Diatron, Hungary). The ESR was estimated manually using Wintrobe's method.

\section{Biochemical evaluation}

Serum biochemical parameters were estimated before and on post-implantation day 7 and 15. Total protein (TP), albumin, glucose, aspartate aminotransferase (AST), alanine aminotransferase (ALT), lactate dehydrogenase (LDH), alkaline phosphatase (ALP), creatine kinase (CK), gamma-glutamyl transferase (GGT), urea, urea nitrogen, creatinine, cholesterol, and triglyceride levels were measured by standard absorptive spectrophotometric methods using commercial test kits supplied from Diatek (India) with an automatic serum biochemical analyzer (Dia-CHEM 240 plus, China). Albuminglobulin ratio $(A: G)$ was calculated mathematically from estimated albumin and total protein contents from sera.

\section{Antioxidants evaluation}

Erythrocytic antioxidants were estimated before and on post-implantation day 7 and 15 . One milliliter of erythrocytic hemolysate was prepared from $20 \mu \mathrm{L}$ of heparinized blood by adding $980 \mu \mathrm{L}$ of $1 \mathrm{X}$ RBC lysis buffer (Himedia, Mumbai, India). Reduced glutathione $(\mathrm{GSH})$ concentration in erythrocytic hemolysate was determined using published method [12]. Catalase activity in erythrocytic hemolysate was estimated spectrophotometrically using double beam UV spectrophotometer (UV2900, Fusiontek, China) at wavelength of $240 \mathrm{~nm}$ after appropriate dilution, as described by Aebi [13]. Decomposition of $\mathrm{H}_{2} \mathrm{O}_{2}$ was followed directly by the decrease in absorbance per min, and it was taken as a measure of the catalase activity.

\section{Statistical analysis}

Data were analyzed by one way analysis of variance. Results were expressed as the mean \pm standard error (SE) of mean. The pair-wise comparison of means was carried out using Tukey's multiple range test. DNA content of native and decellularized tissues was compared by an independent sample t-test. A difference with value $\mathrm{P}<0.05$ was considered statistically significant.

\section{RESULTS}

\section{Characterization of the BDM \\ Histology}

Histologically, native diaphragm (ND) showed cell nuclei (Figure1 (A); H\&E; X 40; scale bar $200 \mu \mathrm{m})$.

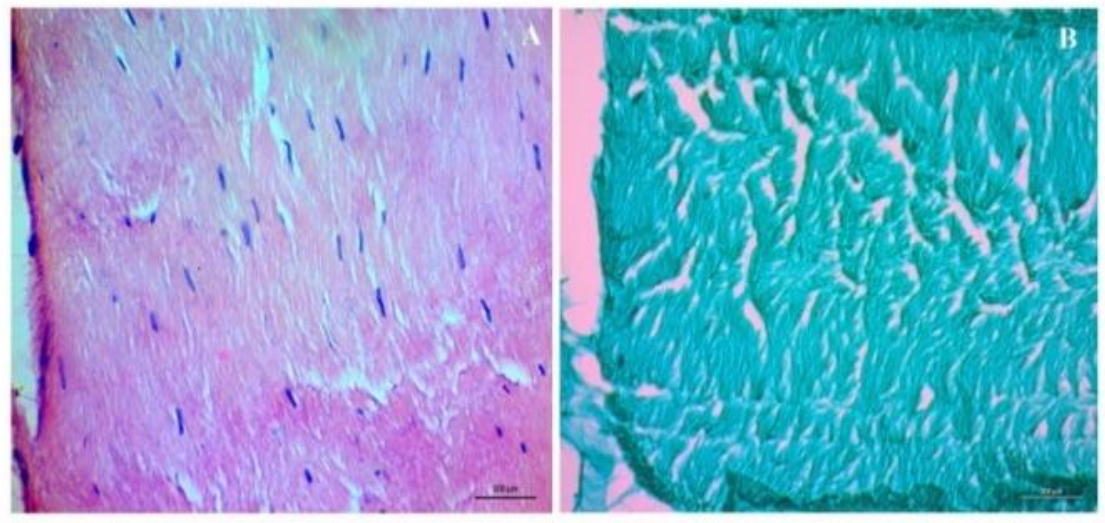

Figure 1. Microscopic images of native diaphragm after hematoxylin-eosin (A), and Masson's trichrome staining (X 40; scale bar $200 \mu \mathrm{m})(B)$. 
Microscopic images of SDS treated diaphragm are shown in Figure 2A-T (H\&E; X 40; scale bar $200 \mu \mathrm{m}$ ). The diaphragm treated with $0.5 \%$ SDS for 12, 24 and $48 \mathrm{~h}$, showed compactly arranged collagen fibers, and cellular debris (Figure $2 \mathrm{~A}-\mathrm{C}$ ). At $72 \mathrm{~h}$ mild porous collagen lattice with presence of cell nuclei were observed (Figure 2D). Treatment with $1 \%$ SDS solution for 12,24 and $48 \mathrm{~h}$ resulted in decrease in cellular components and debris, moderate porosity and preserved collagen structure (Figure $2 \mathrm{E}-\mathrm{G})$. At $72 \mathrm{~h}$ collagen fibers were thin, moderately loose with moderate porosity (Figure 2E-H). Treatment with $2 \%$ SDS solution for 12 and $24 \mathrm{~h}$ showed wellpreserved collagen architecture with sporadic presence of cells (Figure 2l-J). At $48 \mathrm{~h}$, complete loss of cell nuclei and well preserved collagen fibers were observed (Fig. 2K). At $72 \mathrm{~h}$, absence of cell nuclei, and thin, highly loose collagen fibers were observed (Figure 2L). Diaphragm treated with 3 and $4 \%$ SDS for 12, 24, 48 and $72 \mathrm{~h}$, showed complete loss of cell nuclei and extensive damage to collagen structure (Figure 2M-T).

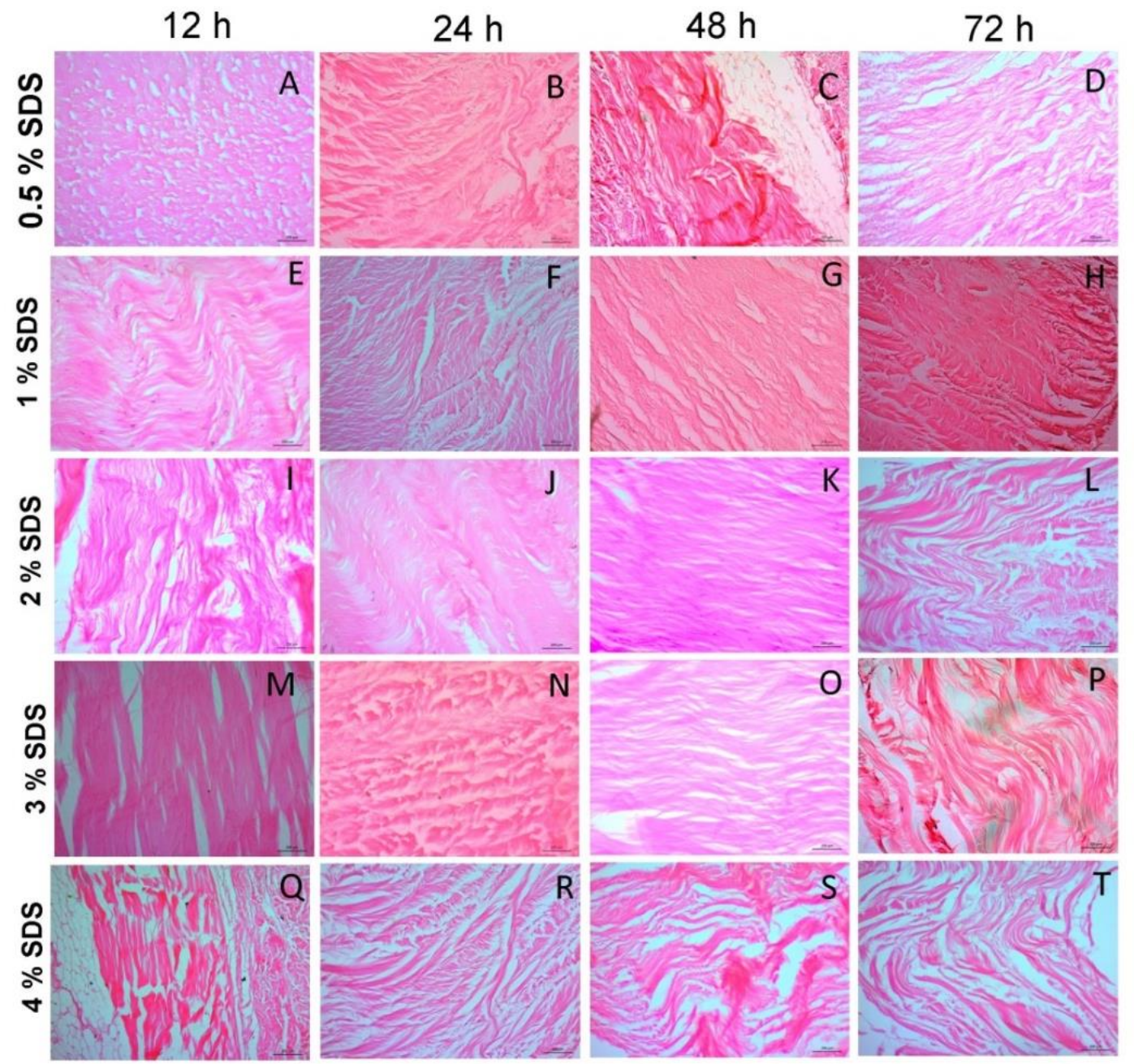

Figure 2. Microscopic images of bubaline diaphragm after treatment with aqueous SDS solutions for 12, 24, 48 and $72 \mathrm{~h}(\mathrm{~A}-\mathrm{T})(\mathrm{H} \& \mathrm{E} ; \mathrm{X} 40$; scale bar $200 \mu \mathrm{m})$.

Masson's trichrome stained images of ND and SDS treated diaphragm are shown in Figure 1B and 3A-T, respectively (X 40; scale bar $200 \mu \mathrm{m}$ ). Treatment of a diaphragm with $2 \%$ SDS solution for $48 \mathrm{~h}$ revealed orderly arranged collagen fibers within BDM (Figure $3 \mathrm{~A}-\mathrm{H}$ ). Treatment of a diaphragm with 3 and $4 \%$ SDS solutions at all incubation period resulted in extensive damage to collagen fibers with increased porosity (Figure 3M-T). 
$12 \mathrm{~h}$
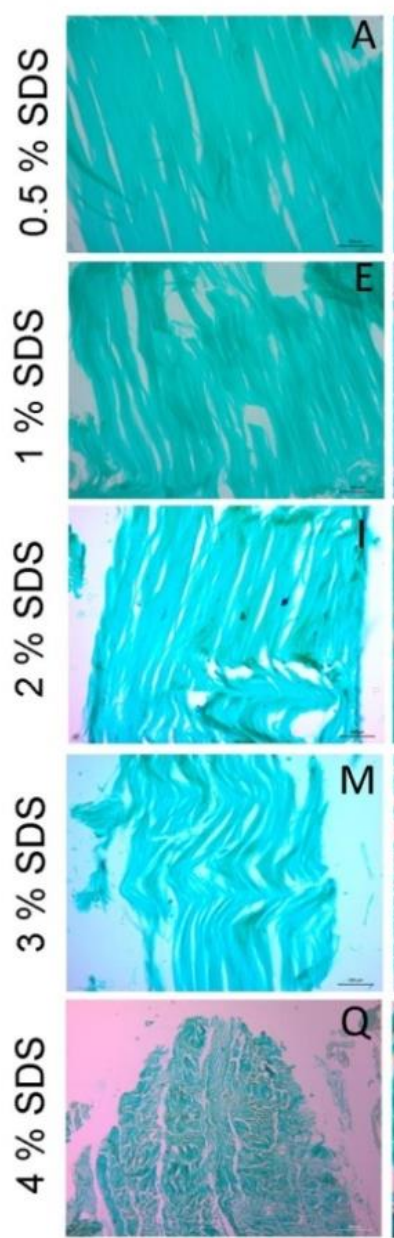

$24 \mathrm{~h}$
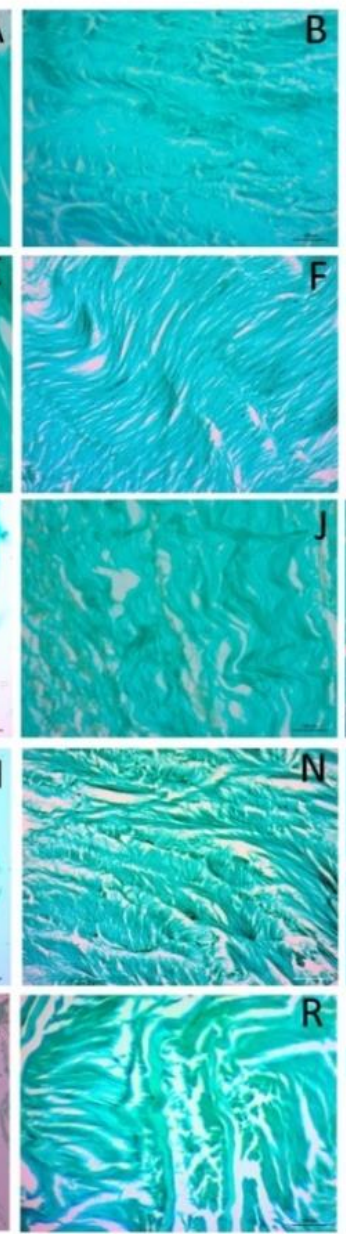

$48 \mathrm{~h}$
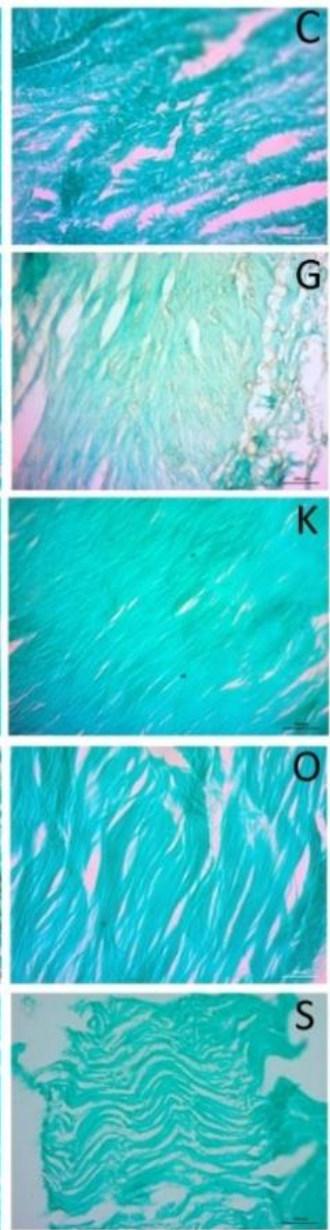

$72 \mathrm{~h}$
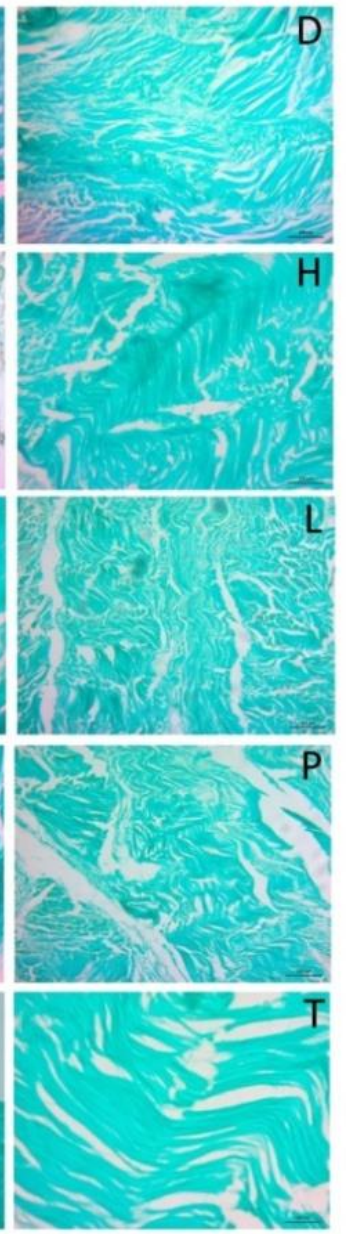

Figure 3. Masson's trichrome stained images of bubaline diaphragm after treatment with aqueous SDS solutions for 12, 24, 48 and $72 \mathrm{~h}(\mathrm{~A}-\mathrm{T})$ (X 40; scale bar $200 \mu \mathrm{m})$.

\section{Scanning electron microscopy (SEM)}

SEM images of ND and BDM are shown in Figure 4. Ultrastructure of the native diaphragm revealed compact collagen fibers with low porosity (Figure 4A-B; $1940 \mathrm{X}$, scale bar $20 \mu \mathrm{m} ; 4540 \mathrm{X}$, scale bar $10 \mu \mathrm{m})$. Thickness of collagen fibers varied between 2.074 and $4.818 \mu \mathrm{m}$. The BDM (treated with $2 \%$ SDS for $48 \mathrm{~h}$ ) showed intact collagen structure and integrity. Thickness of collagen fibers was slightly lesser as compared to the native diaphragm, and varied between 1.454 and $4.154 \mu \mathrm{m}$ (Figure $4 \mathrm{C} ; 4540 \mathrm{X}$, scale bar $10 \mu \mathrm{m})$. 

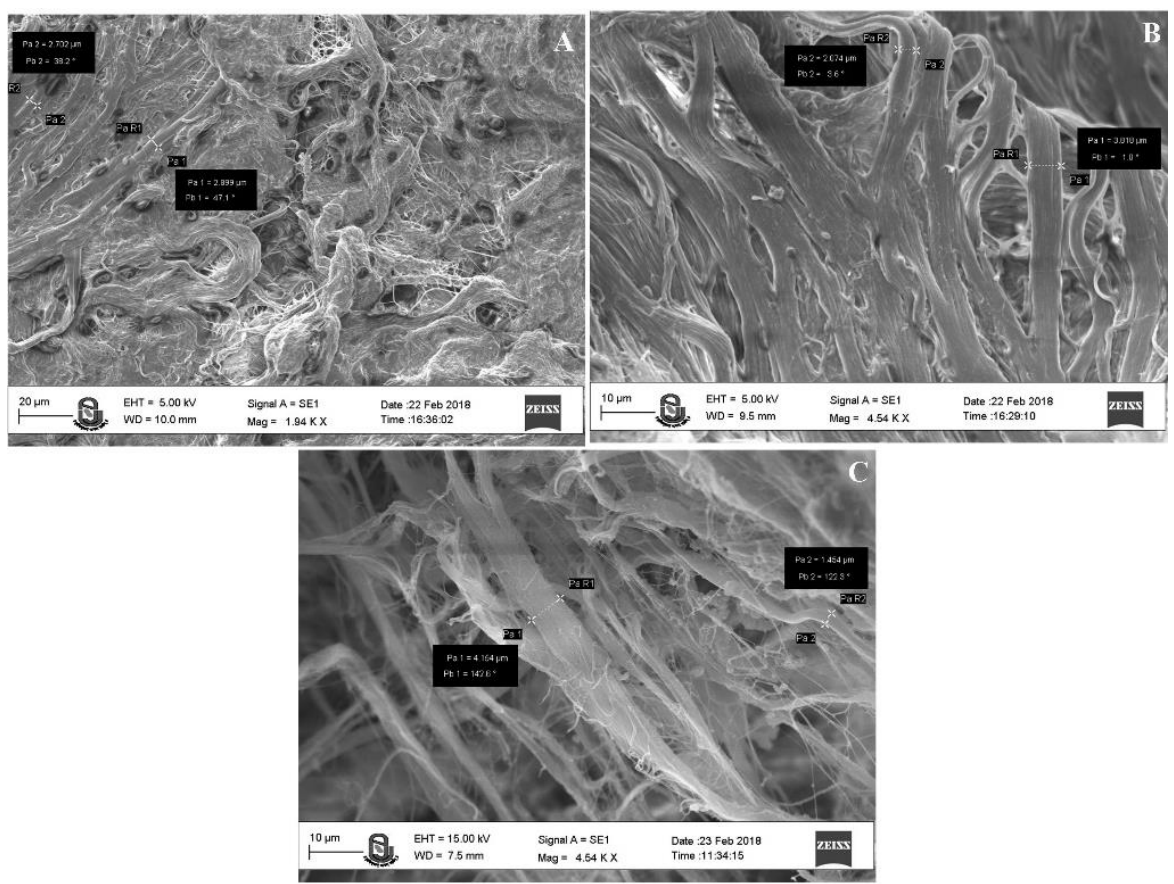

Figure 4. SEM images of native diaphragm (ND) (A-B), and bubaline diaphragm matrix (BDM) (C)

\section{DNA extraction, quantification and purity}

Extracted DNA from ND and BDM was of high purity as evident by the 260/280 ratios. DNA content was $433.96 \pm 162.60 \mathrm{ng} / \mathrm{mg}$, and $33.12 \pm 5.40 \mathrm{ng} / \mathrm{mg}$ in ND and BDM, respectively. DNA content was significantly $(P=0.045)$ decreased in BDM as compared to ND (Figure 5A). Treatment with $2 \%$ SDS for $48 \mathrm{~h}$ resulted in $92.54 \%$ reductions in DNA content of the diaphragm. DNA fragmentation was confirmed through agarose gel electrophoresis. DNA extracts from native diaphragm show broad band indicative of large DNA fragments (Figure 6, Lane 3). Extracts from decellularized diaphragm tissue show considerable removal of DNA material, with absence of DNA band (Figure 5B, Lane 4). This is indicative of effective removal of remnant DNA from developed BDM.
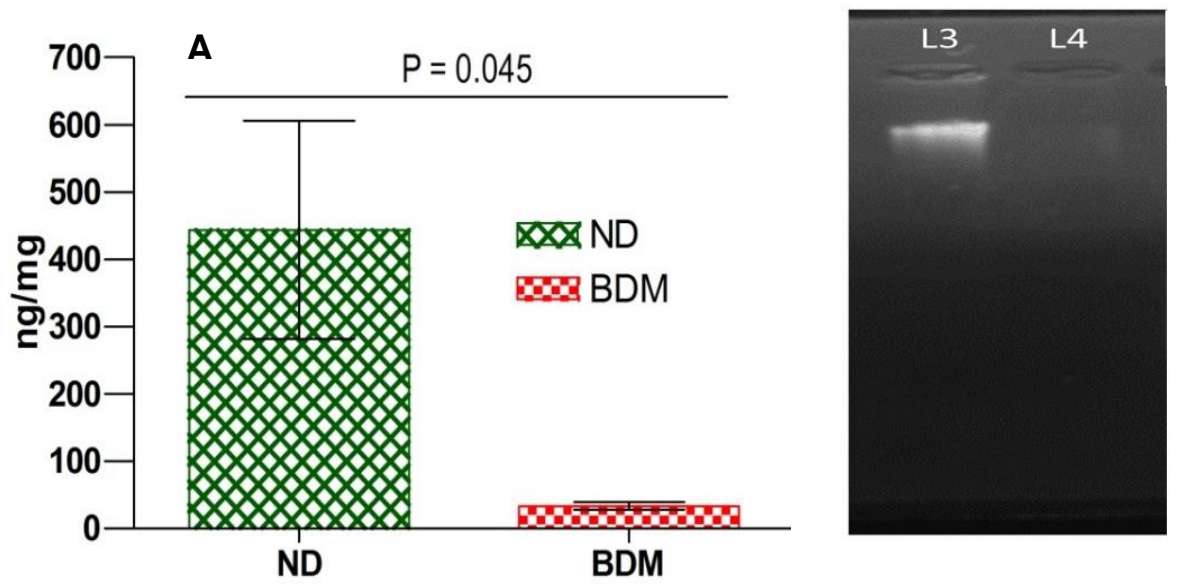

Figure 5. DNA content ( $\mathrm{ng} / \mathrm{mg}$ of tissue) (mean $\pm \mathrm{SE}$ ) in native diaphragm (ND) and bubaline diaphragm matrix (BDM) (A); Ethidium Bromide stained agarose gel image showing DNA band $(\mathrm{L}-3=\mathrm{ND}, \mathrm{L}-4=\mathrm{BDM})(\mathrm{B})$. 


\section{Fourier transform infrared (FTIR) spectroscopy}

FTIR spectra of ND and BDM are shown in the Figure 6 . The amide A band $\left(3294 \mathrm{~cm}^{-}\right.$ ${ }^{1}$ ) is associated with $\mathrm{H}$-bonded $\mathrm{N}-\mathrm{H}$ stretching ${ }^{14}$ and was found at $3386.15 \mathrm{~cm}^{-1}$ for ND and $3343.71 \mathrm{~cm}^{-1}$ for BDM. The amide $\mathrm{B}$ band $\left(2953\right.$ and $\left.2928 \mathrm{~cm}^{-1}\right)$ is related to $\mathrm{CH}_{2}$ asymmetric stretching [15] and was observed at $2955.04 \mathrm{~cm}^{-1}$ for ND and $2954.08 \mathrm{~cm}^{-1}$ for BDM. The amide I band $\left(1641-1658 \mathrm{~cm}^{-1}\right)$ is associated with $\mathrm{C}=\mathrm{O}$ hydrogen bonded stretching [16] as recorded at $1657.87 \mathrm{~cm}^{-1}$ for ND and $1649.19 \mathrm{~cm}^{-1}$ for BDM. The amide II (1539-1546 $\left.\mathrm{cm}^{-1}\right)$ is associated with $\mathrm{C}-\mathrm{N}$ stretching and $\mathrm{N}-\mathrm{H}$ in plane bending from amide linkages, including wagging vibrations of $\mathrm{CH}_{2}$ groups from the glycine backbone and proline side-chains [17] in ND and BDM appeared at $1535.39 \mathrm{~cm}^{-1}$ and $1534.11 \mathrm{~cm}^{-1}$, respectively. The amide III band was found at $1238.34 \mathrm{~cm}^{-1}$ for ND and $1220.02 \mathrm{~cm}^{-1}$ for BDM confirming presence of hydrogen bonds [18].
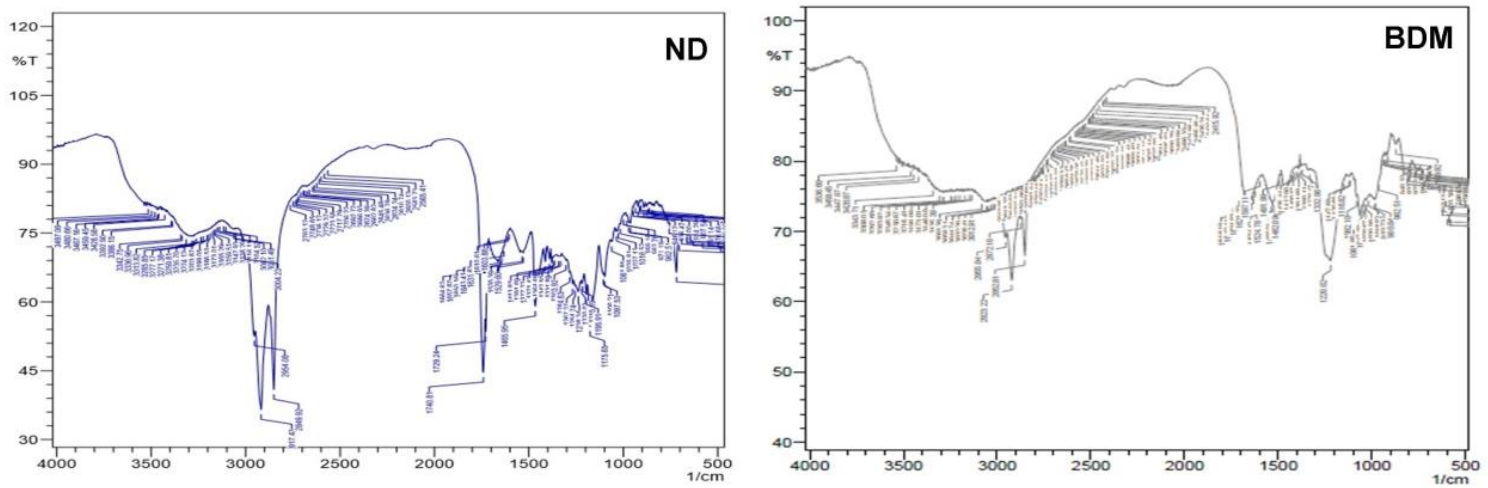

Figure 6. FTIR spectra showing peaks of the native diaphragm (ND) at 1238.34, 1535.39, 1657.87, 2955.04 and $3386.15 \mathrm{~cm}^{-1}$; bubaline diaphragm matrix (BDM) at 1220.02, 1534.11, $1649.19,2954.08$ and $3343.71 \mathrm{~cm}^{-1}$.

\section{Implantation of the BDM in cattle and evaluation \\ Clinical evaluation}

Body temperature, and respiratory and heart rates did not change significantly $(P>$ 0.05 ) on day 7 and 15 as compared to their respective day 0 values. Mild inflammatory edema was observed during first 4 days after surgery. It was gradually decreased on day 10 . On day 15 , incision site healing was normal with healthy epithelization. All animals were observed up to 6 months after implantation and the xenogenic BDM was found healthy.

\section{Hematological evaluation}

The detailed hematological findings are presented in Table 1. Hemoglobin, PCV, TEC, TLC, lymphocytes, monocytes, neutrophils, basophils and eosinophils did not change significantly $(P>0.05)$ on day 7 and 15 as compared to their respective day 0 values. The ESR was significantly $(P<0.05)$ lower on day 15 as compared to day 0 value. 
Table 1. Hematological findings (mean \pm SE) before and after implantation of xenogenic BDM scaffold.

\begin{tabular}{llll}
\hline \multicolumn{4}{c}{ Days } \\
\hline Parameters & $\mathbf{0}$ & $\mathbf{7}$ & $\mathbf{1 5}$ \\
\hline $\mathrm{Hb}(\mathrm{g} / \mathrm{dL})$ & $9.20 \pm 0.38^{\mathrm{a}}$ & $9.93 \pm 0.71^{\mathrm{a}}$ & $9.90 \pm 0.75^{\mathrm{a}}$ \\
$\mathrm{PCV}(\%)$ & $31.02 \pm 2.80^{\mathrm{a}}$ & $30.58 \pm 1.96^{\mathrm{a}}$ & $27.27 \pm 2.67^{\mathrm{a}}$ \\
$\mathrm{TEC}\left(\times 10^{6} \mu \mathrm{L}\right)$ & $8.44 \pm 0.69^{\mathrm{a}}$ & $9.61 \pm 0.94^{\mathrm{a}}$ & $8.37 \pm 0.54^{\mathrm{a}}$ \\
TLC $\left(\times 10^{3} \mu \mathrm{L}\right)$ & $13.13 \pm 0.94^{\mathrm{a}}$ & $13.02 \pm 0.80^{\mathrm{a}}$ & $13.11 \pm 0.62^{\mathrm{a}}$ \\
Lymphocyte $(\%)$ & $56.88 \pm 4.33^{\mathrm{a}}$ & $53.55 \pm 3.74^{\mathrm{a}}$ & $49.57 \pm 5.60^{\mathrm{a}}$ \\
Monocyte $(\%)$ & $4.15 \pm 1.50^{\mathrm{a}}$ & $4.90 \pm 1.46^{\mathrm{a}}$ & $4.97 \pm 1.48^{\mathrm{a}}$ \\
Neutrophil $(\%)$ & $37.00 \pm 5.96^{\mathrm{a}}$ & $37.92 \pm 3.58^{\mathrm{a}}$ & $41.07 \pm 5.24^{\mathrm{a}}$ \\
Basophil $(\%)$ & $0.017 \pm 0.017^{\mathrm{a}}$ & $0.050 \pm 0.050^{\mathrm{a}}$ & $0.083 \pm 0.048^{\mathrm{a}}$ \\
ESR $(\mathrm{mm} / \mathrm{h})$ & $16.33 \pm 1.38^{\mathrm{a}}$ & $13.50 \pm 1.52^{\mathrm{ab}}$ & $11.0 \pm 1.10^{\mathrm{b}}$ \\
\hline
\end{tabular}

Superscript (alphabet) indicates level of significance $(P<0.05)$ on different days.

\section{Biochemical evaluation}

The detailed serum biochemical findings are shown in Table 2. Serum total protein (TP), albumin, globulin, albumin-globulin ratio $(A: G)$, glucose, urea, urea nitrogen, cholesterol, triglyceride, ALP, LDH, CK, ALT, AST, and GGT level did not changed significantly $(P>0.05)$ on day 7 and 15 as compared to their day 0 value. However, serum creatinine concentration was significantly $(P<0.05)$ decreased on postoperative day 7 as compared to their day 0 value.

Table 2. Serum biochemical findings (mean \pm SE) before and after implantation of xenogenic BDM scaffold.

\begin{tabular}{llll}
\hline \multicolumn{4}{c}{ Days } \\
\hline Parameters & $\mathbf{0}$ & $\mathbf{7}$ & $\mathbf{1 5}$ \\
\hline Total protein $(\mathrm{g} / \mathrm{dL})$ & $6.66 \pm 0.42^{\mathrm{a}}$ & $5.41 \pm 0.32^{\mathrm{a}}$ & $6.43 \pm 0.28^{\mathrm{a}}$ \\
Albumin $(\mathrm{g} / \mathrm{dL})$ & $2.33 \pm 0.08^{\mathrm{a}}$ & $3.58 \pm 0.80^{\mathrm{a}}$ & $2.30 \pm 0.08^{\mathrm{a}}$ \\
Globulin $(\mathrm{g} / \mathrm{dL})$ & $4.34 \pm 0.40^{\mathrm{a}}$ & $3.50 \pm 0.29^{\mathrm{a}}$ & $4.13 \pm 0.26^{\mathrm{a}}$ \\
A:G ratio & $0.56 \pm 0.06^{\mathrm{a}}$ & $1.07 \pm 0.25^{\mathrm{a}}$ & $0.57 \pm 0.05^{\mathrm{a}}$ \\
Glucose $(\mathrm{mg} / \mathrm{dL})$ & $75.00 \pm 9.10^{\mathrm{a}}$ & $74.17 \pm 4.46^{\mathrm{a}}$ & $72.00 \pm 11.86^{\mathrm{a}}$ \\
Creatinine $(\mathrm{mg} / \mathrm{dL})$ & $1.39 \pm 0.30^{\mathrm{a}}$ & $0.61 \pm 0.15^{\mathrm{b}}$ & $1.16 \pm 0.04^{\mathrm{ab}}$ \\
Urea $(\mathrm{mg} / \mathrm{dL})$ & $25.00 \pm 4.11^{\mathrm{a}}$ & $23.65 \pm 3.11^{\mathrm{a}}$ & $24.95 \pm 4.94^{\mathrm{a}}$ \\
SUN $(\mathrm{mg} / \mathrm{dL})$ & $11.68 \pm 1.92^{\mathrm{a}}$ & $11.05 \pm 1.46^{\mathrm{a}}$ & $11.66 \pm 2.10^{\mathrm{a}}$ \\
Cholesterol $(\mathrm{mg} / \mathrm{dL})$ & $221.0 \pm 10.16^{\mathrm{a}}$ & $170.33 \pm 25.64^{\mathrm{a}}$ & $200.50 \pm 19.92^{\mathrm{a}}$ \\
Triglyceride $(\mathrm{mg} / \mathrm{dL})$ & $48.33 \pm 9.90^{\mathrm{a}}$ & $31.67 \pm 8.26^{\mathrm{a}}$ & $48.33 \pm 12.15^{\mathrm{a}}$ \\
ALT $(\mathrm{IU} / \mathrm{L})$ & $26.42 \pm 6.52^{\mathrm{a}}$ & $21.49 \pm 4.05^{\mathrm{a}}$ & $31.66 \pm 6.57^{\mathrm{a}}$ \\
AST $(\mathrm{IU} / \mathrm{L})$ & $73.87 \pm 15.33^{\mathrm{a}}$ & $68.32 \pm 5.99^{\mathrm{a}}$ & $87.74 \pm 10.22^{\mathrm{a}}$ \\
LDH (IU/L) & $2000.43 \pm 245.58^{\mathrm{a}}$ & $1884.76 \pm 169.18^{\mathrm{a}}$ & $2180.72 \pm 194.70^{\mathrm{a}}$ \\
CK (IU/L) & $262.99 \pm 73.94^{\mathrm{a}}$ & $349.55 \pm 80.21^{\mathrm{a}}$ & $193.28 \pm 33.46^{\mathrm{a}}$ \\
GGT (IU/L) & $4.66 \pm 0.86^{\mathrm{a}}$ & $3.86 \pm 0.49^{\mathrm{a}}$ & $8.30 \pm 3.94^{\mathrm{a}}$ \\
\hline
\end{tabular}

Superscript (alphabet) indicates level of significance $(P<0.05)$ on different days.

\section{Antioxidant evaluation}

Reduced glutathione (GSH) and catalase activity in erythrocytic hemolysate of cattle are shown in Table 3. GSH level and catalase activity did not change significantly ( $P$ > 0.05 ) on day 7 and 15 as compared to their day 0 value. 
Table 3. Erythrocytic antioxidant findings (mean \pm SE) before and after implantation of xenogenic BDM scaffold.

\begin{tabular}{llll}
\hline \multicolumn{4}{c}{ Days } \\
\hline Antioxidants & $\mathbf{0}$ & $\mathbf{7}$ & $\mathbf{1 5}$ \\
\hline GSH $(\mathrm{mmol} / \mathrm{L})$ & $4.12 \pm 0.59^{\mathrm{a}}$ & $2.74 \pm 0.62^{\mathrm{a}}$ & $3.53 \pm 0.61^{\mathrm{a}}$ \\
Catalase $(\mathrm{U} / \mathrm{mL})$ & $2.35 \pm 0.56^{\mathrm{a}}$ & $1.50 \pm 0.16^{\mathrm{a}}$ & $1.97 \pm 0.28^{\mathrm{a}}$ \\
\hline
\end{tabular}

Superscript (alphabet) indicates level of significance $(P<0.05)$ on different days.

\section{DISCUSSION}

The increasing use of bioscaffolds for tissue repair has prompted its development. They are typically prepared after decellularization of source tissues. Carpo et al. have suggested that no visible nuclei per histologic evaluation via eosin and hematoxylin is a part of the minimum criteria for effective decellularization in terms of the DNA content remaining in decellularized biological scaffolds [19].In the present study, xenogenic BDM scaffold was developed from fresh diaphragm of buffalo origin using aqueous SDS solution. SDS was used in the present study because it is readily available, cost effective and has been used for decellularization of other biological tissues such as aorta [11] and skin [20,21]. Histologically, treatment of fresh diaphragm with $2 \%$ SDS solution for $48 \mathrm{~h}$ resulted in complete loss of cell nuclei, and retention of the distinctive, natural, three-dimensional structures of the collagen within developed matrix. SDS, an ionic detergent, is effective for solubilizing both cytoplasmic and nuclear cellular membranes [22]. It is typically more effective for removing cell residues from tissue compared to other detergents [23]. Further, SEM examination also confirmed effective decellularization of the bubaline diaphragm and preservation of collagen structure and integrity within BDM.

A recent method to assess effective decellularization of xenogenic tissue is by quantification of remnant DNA [7]. DNA retained in decellularized tissues may induce an immune response and foreign body reaction by the host to scaffold implants. Carpo et al. have suggested that $50 \mathrm{ng} / \mathrm{mg}$ dry weight is a part of the minimum criteria for effective decellularization in terms of the DNA content remaining in decellularized biological matrices [19].This value was approached with In the present study, DNA content was significantly $(P=0.045)$ lesser in BDM as compared to the native diaphragm. Treatment with $2 \%$ SDS solution for $48 \mathrm{~h}$ resulted in almost complete reduction in DNA content, indicating effective acellularity. Absence of DNA band on Ethidium Bromide stained agarose gel further indicating loss of DNA from the prepared matrix.

FTIR spectroscopy is used to characterize functional groups of chemical compounds [8]. In the present study, FTIR spectrum of BDM shows all characteristic transmittance peaks of collagen [14-18]. The amide A (NH stretch coupled with hydrogen bonding) and amide $\mathrm{B}\left(\mathrm{CH}_{2}\right.$ asymmetrical stretch) peaks of the BDM (3343.71 and $2954.08 \mathrm{~cm}^{-1}$, respectively) were similar to ND (3386.15 and $2955.04 \mathrm{~cm}^{-1}$, respectively). The amide I $\left(\mathrm{C}=\mathrm{O}\right.$ stretch, and hydrogen bonding coupled with $\mathrm{COO}^{-}$), amide II ( $\mathrm{NH}$ bend coupled CN stretch) and amide III (NH bend) peaks of the BDM (1649.19, 1534.11 and 1220.02 $\mathrm{cm}^{-1}$, respectively) were similar to ND $\left(1657.87,1535.39\right.$ and $1535.39 \mathrm{~cm}^{-1}$, respectively). Based on the location of amide $A$, amide $B$, amide I, amide II and amide III peaks, it seems that developed BDM was composed of collagen.

In the present study, retroperitoneal placement of the BDM scaffold resulted in complete healing without any postoperative complications in all the clinical cases of the abdominal hernia. Decellularized matrices prepared from tissues provide a natural scaffold for repair and regeneration of lost soft tissues [11,20,21,24-26].

The ESR is generally increased in response to inflammation. A significantly $(P<0.05)$ lower ESR on implantation day 15 indicates lesser inflammatory response on implantation. Antioxidants like reduced glutathione $(\mathrm{GSH})$ and catalase play an 
important role in scavenging reactive oxygen species (ROS) that protect the body from oxidative damage [27]. In the present study, a non-significant $(P>0.05)$ change was observed in GSH activity and catalase levels of animals, indicating absence of oxidative stress following implantation. Similar findings were also reported in buffaloes after xenogenic application of caprine acellular dermal matrix [28].

\section{CONCLUSIONS}

The bubaline diaphragm, upon treatment with $2 \%$ SDS for $48 \mathrm{~h}$, results in complete removal of cells and cellular components, with preservation of collagen structure and integrity. Xenogenic bubaline diaphragm matrix shows excellent repair efficiency and biocompatibility for abdominal wall repair in cattle without complications.

Funding: This research received no external funding.

Acknowledgments: This research includes a part of MVSc thesis of the first author approved by Junagadh Agricultural University (JAU) and was supported by the Director of Research, JAU, Gujarat (India).

Conflicts of Interest: The authors declare no conflict of interest.

\section{REFERENCES}

1. Kingsnorth A, LeBlanc KA. Hernias: inguinal and incisional. Lancet. 2003;302:1561-71.

2. Tabata $\mathrm{Y}$. Biomaterial technology for tissue engineering applications. J R Soc Interface 2009;6(Suppl):311-24.

3. Gock H, Murray-Segal L, Salvaris E, Cowan P, D'Apice AJ. Allogeneic sensitization is more effective than xenogeneic sensitization in eliciting Gal-mediated skin graft rejection. Transplant. 2004;77(5):751-3.

4. Xu H, Wan H, Sandor M, Qi S, Ervin F, Harper JR, et al. Host response to human acellular dermal matrix transplantation in a primate model of abdominal wall repair. Tissue Eng Part A. 2008;14:2009-19.

5. Brown BN, Valentin JE, Stewart-Akers AM, McCabe GP, Badylak SF. Macrophage phenotype and remodeling outcomes in response to biologic scaffolds with and without a cellular component. Biomaterials. 2009;30:1482-91.

6. Deeken CR, White AK, Bachman SL, Ramshaw BJ, Cleveland DS, Loy TS, et al. Method of preparing a decellularized porcine tendon using tributyl phosphate. J Biomed Mater Res B Appl Biomater. 2010;96:199-206.

7. Londono R, Dziki JL, Haljasmaa E, Turner NJ, Leifer CA, Badylak SF. The effect of cell debris within biologic scaffolds upon the macrophage response. J Biomed Mater Res A. 2017;105:2109-18.

8. Baker MJ, Trevisan J, Bassan P, Bhargava R, Butler HJ, Dorling KM, et al. Using Fourier transform IR spectroscopy to analyze biological materials. Nat Protoc. 2014;8:1771-91.

9. Ellis DI, Goodacre R. Metabolic fingerprinting in disease diagnosis: biomedical applications of infrared and Raman spectroscopy. Analyst. 2006;131:875-85.

10. Green MR, Sambrook J. Isolation of high-molecular-weight DNA using organic solvents. Cold Spring Harb Protoc. 2017. doi:10.1101/pdb.prot093450.

11. Kumar V, Devarathnam J, Gangwar AK, Kumar N, Sharma AK, Pawde AM, et al. Use of acellular aortic matrix for reconstruction of abdominal hernias in buffaloes. Vet Rec. 2012;170(15):392.

12. Ellman GL. Tissue sulfhydryl groups. Arch Biochem Biophys. 1959;82(1):70-7.

13. Aebi H. Catalase in vitro. Methods Enzymol. 1984;105:121-6.

14. Doyle BB, Bendit E, Blout ER. Infrared spectroscopy of collagen and collagen-like polypeptides. Biopolymers. 1975;14:937-57.

15. Abe Y, Krimm S. Normal vibrations of crystalline polyglycine II. Biopolymers. 1972;11(9):1817-39. 
16. Payne K, Veis A. Fourier transform IR spectroscopy of collagen and gelatin solutions: deconvolution of the amide I band for conformational studies. Biopolymers. 1988;27(11):1749-60.

17. Krimm S, Bandekar J. Vibrational spectroscopy and conformation of peptides, polypeptides, and proteins. Adv Protein Chem. 1986;38:181-364.

18. Muyonga JH, Cole CGB, Duodu KG. Characterisation of acid soluble collagen from skins of young and adult Nile perch (Latesniloticus). Food Chem. 2004;85:81-9.

19. Crapo PM, Gilbert TW, Badylak SF. An overview of tissue and whole organ decellularisation processes. Biomaterials. 2011;32:3233-43.

20. Kumar V, Gangwar AK, Mathew DD, Ahmad RA, Saxena AC, Kumar N. Acellular dermal matrix for surgical repair of ventral hernia in horses. J Equine Vet Sci. 2013;33(4):238-43.

21. Kumar V, Gangwar AK, Kumar N. Evaluation of the murine dermal matrix as a biological mesh in dogs. Proc Natl Acad Sci India Sect B Biol Sci. 2016;86(4):953-60.

22. Seddon AM, Curnow P, Booth PJ. Membrane proteins, lipids and detergents: not just a soap opera. Biochim Biophys Acta. 2004;1666:105-17.

23. Woods T, Gratzer PF. Effectiveness of three extraction techniques in the development of a decellularized bone-anterior cruciate ligament-bone graft. Biomaterials. 2005;26:7339-49.

24. Kumar V, Kumar N, Gangwar AK, Singh $\mathrm{H}$. Comparison of acellular small intestinal matrix (ASIM) and 1-ethyl-3-(3-dimethylaminopropyl)carbodiimidecrosslinked ASIM (ASIM-EDC) for repair of full-thickness skin wounds in rabbits. Wound Med. 2014;7(1):24-33.

25. Gangwar AK, Kumar N, Devi KS, Kumar V, Singh R. Primary chicken embryo fibroblasts seeded 3-D acellular dermal matrix (3-D ADM) improve regeneration of full thickness skin wounds in rats. Tissue Cell. 2015;47(1):311-22.

26. Kumar V, Kumar N, Gangwar AK, Singh H, Singh R. Comparative histological and immunological evaluation of 1,4-butanediol diglycidyl ether crosslinked versus noncrosslinked acellular swim bladder matrix for healing of full-thickness skin wounds in rabbits. J Surg Res. 2015;197(2):436-46.

27. Preville X, Salvemini F, Giraud S, Chaufour S, Paul C, Stepien G, et al. Mammalian small stress proteins protect against oxidative stress through their ability to increase glucose-6phosphate dehydrogenase activity and by maintaining optimal cellular detoxifying machinery. Exp Cell Res. 1999;247:61-78.

28. Asodiya FA, Kumar V, Vora SD, Singh VK, Fefar DT, Gajera HP. Preparation, characterization and xenotransplantation of caprine acellular dermal matrix. Xenotransplantation (accepted). 2019.

2018 by the authors. Submitted for possible open access publication under the terms and conditions of the Creative Commons Attribution (CC BY NC) license (https://creativecommons.org/licenses/by-nc/4.0/). 